\title{
ПЕДАГОГІЧНА КОМПАРАТИВІСТИКА ТА ФОРМУВАННЯ ЧИТАЦЬКОЇ КОМПЕТЕНТНОСТІ НА УРОКАХ ЗАРУБІЖНОЇ ЛІТЕРАТУРИ
}

\author{
Mukachevo State University \\ PEDAGOGICAL COMPARATIVE STUDIES AND FORMATION OF \\ READING COMPETENCE IN FOREIGN LITERATURE LESSONS
}

\begin{abstract}
Анотація. У статті зазначено, що з кінця 80-х рр. ХХ ст. національна педагогічна компаративістика почала позбавлятися комплексу меншовартості. Наголошено, що багато часу піддавалася критиці більшість представників зарубіжної педагогіки («апологети буржуазії» та проповідники «реакційних», «антинаукових рухів»), оскільки вони суперечили канонізованій марксистсько-ленінській педагогіці. Зауважено на працях відомих вчених, таких, як Д. Скільський, В. Кравець, К. Лучаковський, які здійснили вагомий внесок у розвиток української компаративістики. У 90-х pp. XX - на початку XXI ст. українська педагогічна компаративістика здійснила поступ у дослідженні педагогічних персоналій закордоння. На тлі вдосконалення ії наукового інструментарію напрацьовано оптимальні методологічні підходи, які дозволяють комплексно, синтезовано, цілісно осмислювати їхні біографії, творчу спадщину та різні напрями суспільної діяльності, що допомагають за певним алгоритмом краще вивчити та дослідити біографію зарубіжних письменників. У статті розглядається роль педагогічної компаративістики та прийомів розвитку креативності на уроках зарубіжної літератури. Зазначено, що необхідно розвивати творчість учнів, використовуючи метод навчання, який допомагає фундаментальному засвоєнню матеріалу, розвитку уяви, самостійну та групову роботу у навчальному колективі. Заняття з використанням креативних методик дозволяють школярам розвивати навички уваги, а також мислити нестандартно. Зауважено на доброзичливому ставленні до учнів, формуванні толерантності до носіїв іншої культури на основі знайомства з життям своїх однолітків в інших країнах. Наголошено, що твори фольклору є доступним зразком художньої літератури. Зосереджена увага на формуванні початкових навичок комунікації, вихованні моральних і естетичних почуттів, розвитку творчої діяльності. Доведено, що уроки зарубіжної літератури є важливою складовою для формування читацької компетентності.
\end{abstract}

Ключові слова: зарубіжна література; компаративістика; творчість; освіта; педагог; розвиток.

Abstract. The article claims that since the end of the 80s of the twentieth century, domestic pedagogical comparative studies have begun to get rid of the inferiority complex. It is noted that most representatives of foreign pedagogy ("apologists of the bourgeoisie” and preachers of "reactionary" and "anti-scientific movements”) were criticized for a long time, as they contradicted the canonized MarxistLeninist pedagogy. This is noted in the works of well-known scientists, such as D. Skilsky, V. Kravets, K. Luchakovsky, who made a significant contribution to the development of Ukrainian comparative research. In the 90s of the XX-beginning of the XXI century. Ukrainian pedagogical comparativistics has made progress in the study of pedagogical personalities abroad. Against the background of improving its scientific tools, optimal methodological approaches were developed that allow them to comprehensively, synthesize, comprehensively comprehend their biographies, creative heritage and various spheres of public activity, which help to better study and research the biography of foreign writers according to a certain algorithm. The article examines the role of pedagogical comparative research and methods of developing creativity in foreign literature lessons. It is noted that it is necessary to develop the creative abilities of students using the teaching method, which contributes to the fundamental assimilation of the material, the development of imagination, independent and group work in the educational team. Classes using creative techniques allow students to develop attention skills, as well as Think outside the box. There is a friendly attitude towards students, the formation of tolerance to carriers of a different culture based on acquaintance with the life of their peers in other countries. It is noted that works of folklore are an accessible example of fiction. The main attention is paid to the formation of initial communication skills, education of moral and aesthetic feelings, and the development of creative activity. It is proved that foreign literature lessons are an important component of the formation of reading competence.

Key words: foreign literature; comparative research; creativity; education; teacher; development.

Вступ. Суспільство сьогодення змінюється швидко, так само прогресує мислення нового покоління. Важливо не втрачати свою індивідуальність, своє власне судження, свій світогляд та, використовуючи гнучкі навички, знаходити прості рішення складних завдань, тим самим виробляти нестандартне мислення. 
Крім того, в кожній складній ситуації необхідно знаходити що-небудь незвичайне, конкретне для кожного, яке, у свою чергу, буде характеризувати нас як індивідуальність. Як правило, в ранньому віці дитини закладається фундамент, який буде впливати на її світогляд, на здатність мислити, вирішувати проблеми.

Мета статті - розкрити педагогічну компаративістику, яка на уроках зарубіжної літератури формує та розвиває читацькі компетентності учнів.

Теоретична частина. Творчість, креативне мислення, різні форми порівняння, зіставлення змінюють і учня, і студента. Слідом за розвитком технологій змінюється життя людей: робота, думки, спілкування. Зокрема, змінюються культурні цінності. Це дає підставу говорити про те, що тисячі людей стикаються з незвичайними і безпрецедентними проблемами. Саме для вирішення такого виду проблем людству необхідні винахідливість, уява і креативність.

Англійський вчений Кен Робінсон вважає, що для людства важливо бути творчим. Це є важливим і для економіки, і для самореалізації особистості. На даний момент виникає потреба в системному розвитку творчості наших дітей.

Академік Г. К. Селевко стверджує: «Свобода творчості розширює розумовий кругозір школяра, підсилює продуктивність його фантазії, викликає позитивні емоції, збуджує його активність, його волю до дії, допомагає з більшою наполегливістю і винахідливістю долати труднощі» [3, с. 27].

Однією з цілей сучасної школи є виховання креативності учнів на уроках зарубіжної літератури. Як керівники, так і вчителі дотримуються тієї думки, що на уроці повинна бути створена відповідна атмосфера, яка буде основним компонентом для творчої думки й діяльності [6], відповідно до цього, слідом за розвитком суспільства, необхідно вдосконалити методики викладання.

Компаративістика - один із шляхів саморефлексії людини. Вміти давати оцінку зовнішнім подіям, аналізувати вчинки літературних героїв, зіставляти художні образи, займатися порівняльним літературознавством, вивчати літературні подібності, аналогії, зв'язки різних національних літератур, виражені через літературні впливи, - одне із завдань сучасних закладів освіти.

3 кінця 80-х рр. ХХ ст. національна педагогічна компаративістика почала позбавлятися комплексу меншовартості. До зазначеного часу піддавалася критиці більшість представників зарубіжної педа- гогіки («апологети буржуазії» та проповідники «реакційних», «антинаукових рухів»), оскільки вони суперечили канонізованій марксистсько-ленінській педагогіці [2, с. 291].

За три наступні десятиріччя українська педагогічна компаративістика пройшла потужний шлях розвитку, нагромадивши значний обсяг конкретнотематичних студій, чимала частина яких присвячена персоналіям зарубіжної педагогіки.

К. Лучаковський у своїх підручниках органічно поєднував твори української й зарубіжної літератури та мови в середній школі наприкінці XIX - на початку XX ст. Його постать посідає особливе місце в історії розвитку українського літературознавства, підручникотворення й українського перекладу 3 класичних мов, методики навчання української та зарубіжної літератури.

Високим рівнем персоніфікації відзначається начальний посібник В. Кравця «Зарубіжна школа і педагогіка XX століття» [1], де порівнюються думки Стародавнього Сходу і доби Античності. Вчений звертає увагу на напрацьовану в біографістиці схему (біографічні дані, формування світогляду, наукова, професійна, громадська діяльність тощо) і презентує знакові постаті світової педагогіки Я. А. Коменського, Й. Песталоцці, І. Гербарта, Д. Дідро, Ж. Ж. Руссо.

Навчальний посібник Д. Скільського «Історія зарубіжної педагогіки: посібник» [4] відзначається стилем викладу матеріалу: згідно $з$ ним, життєдіяльність, творчість визначних просвітителів і педагогів Середньовіччя та педагогічної думки окремих країн (Англії, Франції, Німеччини, Росії та ін.) XVII - початку XX століть подаються у вигляді основної текстової частини, яка доповнюється логічно-структурними схемами, фрагментами творів, фотографіями, ілюстраціями тощо.

У межах української педагогічної компаративістики активно формується окремий персоніфікований напрям, тож ця проблема потребує спеціального вивчення. На подальший розвиток заслуговують порівняльні студії, які зіставляють життєвий шлях і творчий доробок зарубіжних та українських педагогічних персоналій, розвиток зарубіжної педагогічної думки.

Літературна компаративістика, історія педагогіки, дидактика, теорія і практика виховання, педагогічна компаративістика, соціальна педагогіка і гуманітарні знання тісно межують між собою [2, с. 7].

3 кінця 80-х pp. XX ст. національна педагогічна компаративістика почала позбавлятися «комп- 
лексу меншовартості», адже раніше дослідження зарубіжної освіти і педагогічної думки в Україні майже не проводилися через монополізацію цієї галузі російськими вченими. Вони в дусі радянських ідеологем піддавали безапеляційній критиці більшість представників зарубіжної педагогіки як «апологетів буржуазії» та проповідників «реакційних», «антинаукових» теорій, які суперечили канонізованій марксистсько-ленінській педагогіці. За три наступні десятиріччя українська педагогічна компаративістика пройшла потужний шлях розвитку, нагромадивши значний обсяг конкретнотематичних студій, чимала частина яких присвячена персоналіям зарубіжної педагогіки [2, с. 391].

За три наступні десятиріччя українська педагогічна компаративістика пройшла потужний шлях розвитку, нагромадивши значний обсяг конкретнотематичних студій, чимала частина яких присвячена персоналіям зарубіжної педагогіки. Зважаючи на виклики глобалізації і євроінтеграції та утвердження нових освітніх і науково-методологічних парадигм, вона змінює пріоритети від нагромадження, систематизації, опису якнайбільшого обсягу інформації про освітні системи різних країн до зіставлення та визначення спільних і відмінних рис їхнього національного досвіду виховання і навчання [2, с. 392].

Вивчати досвід викладачів зарубіжжя - надзвичайно цікаво і корисно. Учитель з Нью-Йорка Стефані Макартур створила проект «Компліменти». Суть даного методу полягає в тому, що один з учнів сідає спиною до дошки. Далі його однокласникам, використовуючи вирази, які вони запам’ятали, читаючи твір (або малюнки, залежно від віку учнів, їх нахилів та здібностей), необхідно заповнити дошку компліментами на адресу того учня, який сидить на стільці. Вирази облич школярів у той момент, коли вони повертаються до дошки, безцінні. Це викликає посмішки, сміх і навіть сльози, звичайно, сльози щастя. А для нас як для викладачів це і $є$ найголовнішим: зацікавити, навчити використовувати набуті знання на практиці. Таке завдання можна ускладнити, якщо учні знають іноземну мову.

Доброзичливе ставлення, формування толерантності до носіїв іншої культури на основі знайомства 3 життям своїх однолітків в інших країнах, з дитячим фольклором і доступними зразками дитячої художньої літератури, формування початкових навичок комунікації, виховання моральних й естетичних почуттів, здібностей до творчої діяльності $є$ важливим чинником педагогічної компаративістики.
Наступним незвичайним прийомом є створення плаката «Знайомство». Ця вправа добре підходить для перших уроків вивчення художнього твору. Під час вивчення, до прикладу, теми «Фольклор» кожен учень створює свою картинку, на якій зображує головну інформацію про твір (опис героя, опис природи, місце дії, улюблені речі художніх образів). Далі картинки збираються в одне загальне панно, яке відобразить весь твір. На його створення піде значна кількість часу, що допомагає вчителю спілкуватися як із класом, так і з кожним учнем індивідуально. Це завдання спонукає школярів розповідати про враження від прочитаного, наголошувати на певному важливому епізоді твору. Основною перевагою методу є те, що учні створюють спільну головоломку, яка служить візуальним уявленням кожної дитини, а також допомагає організувати групову роботу та єдність у класі [7].

Ще однією дуже цікавою вправою є «Розповідьмалюнок». Учитель читає уривок твору, і під час прослуховування учні на аркуші паперу, в зошиті або на дошці малюють те, про що йдеться в оповіданні. Це завдання також можна проводити в іншому порядку. Школярі складають вигадану розповідь за малюнками, які намалювали їхні однокласники. Виконуючи таку творчу роботу, учні тим самим демонструють своє знання послідовності тексту, тренують свою уяву, художній вимисел. У результаті даного методу, використовуючи на уроці зарубіжної літератури свої вміння, учні розширюють свій словниковий запас, й одночасно отримують велику кількість приємних емоцій [7].

Цікавим i, водночас, творчим видом роботи на уроці зарубіжної літератури є завдання: «Створи свій текст». Перш за все, це традиційний твір. Основними жанрами літературної творчості є відомі всім характеристика героя, літературний портрет, рецензія, літературно-критична стаття, розповідь, нарис, есе, репортаж, лист. При цьому учні навчаються практично опановувати елементи художнього, публіцистичного, науково-популярного стилів, що надає можливість сприяти креативному підходу до вивчення не тільки теорії літератури, а і розвивати «письменницькі» здібності.

Висновки та перспективи подальших досліджень. Отже, у 90-х рp. XX - на початку XXI ст. українська педагогічна компаративістика здійснила поступ у дослідженні педагогічних персоналій закордоння. На тлі вдосконалення її наукового інструментарію напрацьовуються оптимальні методологічні підходи, які дозволяють комплексно, 
синтезовано, цілісно осмислювати їхні біографіï, творчу спадщину та різні напрями суспільної діяльності. Урізноманітнюються тематичні вектори цього персоніфікованого напряму, зокрема у вигляді предметного вивчення окремих визначальних складників авторських концепцій і систем, зіставлення надбань відомих зарубіжних та українських педагогів тощо. У його розвитку залишається чимало вузьких місць, прогалин [2, с. 420].

Розвиток творчих здібностей має на меті використання синергетичного підходу щодо навчання. Шкільні предмети тісно взаємопов’язані,

\section{Список літератури}

1. Кравець В. П. Зарубіжна школа і педагогіка ХХ століття / В. П. Кравець. - Тернопіль, 1996. - 287 с.

2. Розман I. I. Українська педагогічна біографістика (друга половина XX - початок XXI століття) : монографія / I. I. Розман. - Ужгород : РІК-У, 2020. - 616 с.

3. Селевко Г. К. Енциклопедія освітніх технологій : у 2-х т. / Г. К. Селевко. - М. : Народна освіта, 2005. T. $1 .-556$ с.

4. Скільський Д. Історія зарубіжної педагогіки : посіб. / Д. Скільський. - К. : Смолоскип, 2011. - С. 90-97.

5. Цюра С. Методологія порівняльних педагогічних досліджень принципи / С. Цюра // Педагогічна

\section{References}

1. Kravets, V.P. (1996). Zarubizhna shkola i pedahohika $X X$ stolittya [Foreign school and pedagogy of the twentieth century]. Ternopil [in Ukrainian].

2. Rozman, I.I. (2020). Ukrayinska pedahohichna biohrafistyka (druha polovyna XX-pochatok XXI stolittya) [Ukrainian pedagogical biography (second half of the $X X$ - beginning of the XXI century)]. Uzhhorod: RIK-U [in Ukrainian].

3. Selevko, H.K. (2005). Entsyklopediya osvitnikh tekhnolohiy: u 2-kh t. [Encyclopedia of educational technologies: in 2 vols.]. (Vol. 1). Moscow: Narodna osvita [in Ukrainian].

4. Skilskyy, D. (2011). Istoriya zarubizhnoyi pedahohiky [History of foreign pedagogy]. Kyiv: Smoloskyp [in Ukrainian].

5. Tsyura, S., \& Lokshyna, I.I. (2015). Metodolohiya porivnyalnykh pedahohichnykh doslidzhen; pryntsypy якщо застосовувати міждисциплінарний підхід: література - історія, історія - мистецтвознавство, мистецтвознавство - географія, географія - література. У педагогіці існує певна саморефлексія, самоорганізація творчості, яка визначає потребу розвитку особистості й суспільства. Відбувається створення соціальних матриць для людей різного рівня творчості. Творчо працюючі вчителі готують підопічних до діяльності за умов спеціально розроблених методик, які підтримують і розвивають особистість у широкому значенні цього слова.

компаративістика - 2015: трансформації в освіті зарубіжжя та український контекст : матеріали наук.практ. семінару (Київ, 11 черв. 2015 р.) / за заг. ред О. I. Локшиної. - К. : Педагогічна думка, 2015. C. 28-29.

6. Developing a positive classroom culture: the compliments PROJECT Topteaching [Electronic resource]. - Access mode : https://topteachingtasks.com/developing-a-positiveclassroom-culture-and-the-compliments-project/.

7. Feher Judit. Creativity in the language classroom [Electronic resource] / Judit Feher. - Access mode : https:// www.teachingenglish.org.uk/article/creativity-languageclassroom.

[Methodology of comparative pedagogical research principles]. Pedahohichna komparatyvistyka - 2015: transformatsiyi $v$ osviti zarubizhzhya ta ukrayinskyy kontekst: materialy nauk.-prakt. seminaru - Pedagogical Comparative Studies - 2015: Transformations in Education Abroad and the Ukrainian Context. Proceedings of the scientific-practical seminar. Kyiv: Pedahohichna dumka [in Ukrainian].

6. Developing a positive classroom culture: the compliments PROJECT Topteaching. Retrieved from: https:// topteachingtasks.com/developing-a-positive-classroomculture-and-the-compliments-project/.

7. Feher, Judit. Creativity in the language classroom. Retrieved from: https:/www.teachingenglish.org.uk/article/ creativity-language-classroom. 